\title{
B.P. Филиппов
}

\author{
Институт Африки Российской академии наук, \\ 123001 г. Москва, Российская Федерация
}

\section{Африканская политика Парижа в период пандемии}

В статье на основе информации, опубликованной во французских средствах массовой информации, рассматривается возможная трансформация геополитической ситуации во франкофонных странах Тропической Африки в условиях пандемии коронавируса. Использован аналитический доклад, направленный экспертами парижского Центра анализа, прогнозирования и стратегии (CAPS), в адрес президента и МИД Франции. В статье содержится перечень основных эпидемиологических, социальных, гуманитарных и политических угроз, которые будут дестабилизировать ситуацию на Черном континенте, а также предпринята попытка прогнозирования динамики международных отношений в посткоронавирусный период. Цель предпринятого исследования выяснить, каким образом изменится соотношение сил традиционных и относительно новых акторов международных отношений в странах Тропической Африки в рассматриваемый период. Особое внимание обращено на инициативы Елисейского дворца, призванные сохранить традиционное политическое, экономическое и военное доминирование Пятой республики в африканских странах, территории которых входили в состав Французской колониальной империи. Проанализированы предложения Эммануэля Макрона относительно списания внешних долгов и экономической помощи африканским странам. Сделан вывод о том, что инициативы президента Франции не могут быть реализованы в политической практике и направлены лишь на противодействие нарастанию антифранцузских настроений в странах Сахеля. Политологический анализ ситуации приводит к заключению о том, что в результате экономических и политических потрясений, вызванных пандемией коронавируса, весьма вероятно вытеснение интересов Франции из стран Тропической Африки Китаем и, отчасти, Россией. 
Ключевые слова: пандемия коронавируса, Тропическая Африка, африканская политика Франции, инициативы Макрона, противостояние Франции и Китая, экономические последствия пандемии, голод в Африке, политический кризис в странах Сахеля

ДЛЯ ЦИТИРОВАНИЯ: Филиппов В.Р. Африканская политика Парижа в период пандемии // Локус: люди, общество, культуры, смыслы. 2020. Т. 11. № 3. C. 151-168. DOl: 10.31862/2500-2988-2020-11-3-151-168

DOI: 10.31862/2500-2988-2020-11-3-151-168

\section{V.R. Filippov}

Institute for African Studies of the Russian Academy of Sciences, Moscow, 123001, Russian Federation

\section{African politics in Paris during the pandemic}

The article discusses the possible transformation of the geopolitical situation in the Francophone countries of Tropical Africa in the context of the coronavirus pandemic, based on the information published in the French media. And also, the analytical report, sent by experts of the Paris Center for Analysis, Forecasting and Strategy (CAPS), to the President and the French Foreign Ministry was used. The article contains a list of the main epidemiological, social, humanitarian, and political threats that will destabilize the situation on the Black Continent, as well asmade a prediction attempt of the dynamics of international relations in the postcoronavirus period. The aim of this study is to find out how the balance of forces of traditional and relatively new actors in international relations has been changed in the countries of Tropical Africa in the period of present observation. Particular attention is paid to the initiatives of the Champs Elysees, designed to preserve the traditional political, economic, and military dominance of the Fifth Republic in African countries, the territories of which were part of the French colonial empire. Emanuel Macron's proposals regarding forgiveness of external debts and economic assistance to African countries are analyzed. It is concluded that the initiatives of the President of France cannot be implemented in political practice and are 
aimed only at countering the growth of anti-French mood in the Sahel. A political analysis of the situation comes to the conclusion that, as a result of the economic and political upheaval caused by the coronavirus pandemic, it is very likely that the interests of France will be supplanted from Tropical Africa by China and, in part, by Russia.

Key words: coronavirus pandemic, Tropical Africa, African policy of France, Macron initiatives, confrontation between France and China, economic consequences of the pandemic, famine in Africa, political crisis in the Sahel

FOR CITATION: Filippov V.R. African politics in Paris during the pandemic. Locus: People, Society, Culture, Meanings. 2020. Vol. 11. No. 3. Pp. 151-168. (In Russ.) DOI: 10.31862/2500-2988-2020-11-3-151-168

Теперь уже мало кто сомневается в том, что мир после пандемии коронавируса будет иным. Экономические, социальные, политические, демографические последствия будут весьма чувствительными и приведут к заметным геополитическим трансформациям во многих регионах мира. Особенно явными эти изменения будут, вероятно, на африканском континенте.

\section{Пандемия коронавируса в Африке}

Первый случай заражения вирусом COVID-19 на африканском континенте был отмечен 13 февраля 2020 г. в Египте. А 13 мая первый случай заражения этим вирусом был зафиксирован в Лесото, в государстве, до того не затронутом инфекцией [22]. Таким образом, за три месяца эпидемия распространилась на все африканские страны без исключения. На 25 августа 2020 г. по данным Африканского отделения (представительства) Всемирной организации здравоохранения (ВО3) в Африке заразились коронавирусом 1200233 человек, болеют 246 942, в критическом состоянии 1212; умерли 28 055, выздоровели 925 236. К сожалению, эти данные весьма условны: сколько-нибудь точно определить число инфицированных не представляется возможным. Проблема состоит в том, что государственные границы в Африке весьма прозрачны, миграционная подвижность населения во многих регионах высокая, государственные системы здравоохранения во многих странах находятся в эмбриональном состоянии, а средств выявления инфекции (тестов на COVID-19) и аппаратов искусственной вентиляции легких (ИВЛ) катастрофически не хватает. Ситуация осложняется тем, что болезнь быстро проникает в труднодоступные сельские регионы, где инфицированных очень трудно найти и диагностировать, а еще труднее будет лечить. 
Специалисты Африканского отделения ВОЗ в исследовании, опубликованном в журнале BMJ Global Health, предсказывают, что за год заразиться коронавирусом может примерно четвертая часть населения Африки. По мнению экспертов, за предстоящие 12 месяцев могут заразиться 166 млн жителей континента (в лучшем случае), в худшем случае - почти 275,7 млн. За год число жертв инфекции может составить 150 тыс. человек. Африка, население которой составляет более 1,2 млрд чел., может стать следующим эпицентром пандемии коронавируса COVID-19.

Эксперты ВО3 полагают, что на африканском континенте вспышка эпидемии будет длиться несколько лет, при этом «внимание, уделяемое сдерживанию распространения вируса, приведет к игнорированию других проблем здравоохранения, а это в свою очередь усилит кумулятивный эффект коронавирусной заболеваемости» [16]. (Не стоит забывать о том, что серьезную угрозу населению континента представляют также ВИЧ, туберкулез, малярия, лихорадка Эбола и другие инфекционные заболевания.) Нужно иметь в виду и тот факт, что миллионы африканцев живут впроголодь, а это радикально влияет на иммунитет. Эксперты обращают внимание на то, что пандемия заставила остановить кампанию по вакцинации детей от кори в таких странах, как Чад, Эфиопия, Нигерия и Южный Судан. По прогнозам ВО3, в результате жертвами кори в этих странах могут стать более 20 млн детей.

В Управлении Верховного комиссара ООН по делам беженцев опасаются того, что продолжающееся насилие в Восточной и Центральной Африке приведет к перемещению десятков или сотен тысяч людей, что даст новый импульс распространению коронавируса и других серьезных заболеваний. Прозрачность границ между африканскими государствами лишает надежды на то, что силовые структуры смогут организовать эффективное ограничение миграционных потоков. Катастрофические последствия может иметь запредельная концентрация людей в лагерях беженцев и вынужденных переселенцев.

Бедность подавляющего большинства африканцев также будет фактором, способствующим распространению COVID-19. Отсутствие или дороговизна средств индивидуальной защиты, скученность населения африканских городов сделают борьбу с болезнью крайне затруднительной.

До последнего времени была надежда на то, что пандемия в Африке не будет столь катастрофичной, как на других континентах. Если проанализировать динамику распространения вируса в мире, то становится ясно, что угрожающие масштабы пандемия приобрела в развитых странах с высокой степенью подвижности населения как внутри государств, 
так и между различными субъектами международного права. Именно массовые перемещения людей (особенно в огромных мегаполисах) в первые недели эпидемии привели к стремительному росту заболеваемости в Китае, США, Италии, Франции, России и пр. Есть основания думать, что относительно низкая подвижность населения в африканских странах затормозила распространение инфекции, особенно в аграрных регионах с доминирующим сельским населением. Вероятно, это станет причиной известного «сдвига» в нарастании темпов и масштабов пандемии. Но те факторы риска, о которых было сказано выше, с очень большой долей вероятности проявят себя в обозримом будущем. Известно, что эпидемия уже широко вышла за пределы столиц стран континента.

\section{Экономические угрозы и гуманитарный кризис}

Однако это лишь прямые угрозы, порожденные пандемией, еще более катастрофичными для населения Черного континента могут стать последствия глобального экономического кризиса, спровоцированного распространением коронавируса. Каждый год треть того, что Африка экспортирует в коммерческих целях, используется для обслуживания долга [13]. Платежи по обслуживанию кредитов стран Черного континента в 2020 г. составляют около 14 млрд дол. [10]. В 2012 г. долги африканских стран составляли $30 \%$ их ВВП, сегодня это уже 95\%. Некоторые африканские страны подвергаются риску дефолта по своим кредитным обязательствам, а частные заемщики на континенте окажутся в бедственном положении, поскольку их бизнес уже разрушен глобальным спадом. Сильнее других уже пострадали страны-экспортеры нефти в Центральной Африке. Эксперты высказывают серьезные опасения по поводу девальвации франка КФА.

ООН предупреждает, что пандемия таит в себе угрозу голода для сотен миллионов африканцев в странах, в огромной степени зависящих от импорта и экспорта продуктов питания. Эксперты Всемирной продовольственной программы (ВПП) считают, что гуманитарный кризис в регионе Сахеля может стать «неуправляемым, и тогда более пяти миллионов человек столкнутся с серьезной проблемой отсутствия продовольствия» [17].

Лидеры африканских государств все настойчивее просят поддержки у экономически развитых государств. Премьер-министр Эфиопии Абий Ахмед предрекает, что человеческие и экономические потери будут огромными для жителей континента, а ущерб не остановится на африканских берегах и страдания африканцев отразятся на всем остальном мире. Он настаивает на том, что Африка нуждается в немедленном 
экстренном финансовом стимулировании на сумму 100 млрд дол. США в дополнение к уже запрограммированной регулярной поддержке Международного валютного фонда, равной 50 млрд дол. США [10]. «Африка очень уязвима перед этим вирусом и нуждается в любой помощи», - заявил недавно президент ЮАР Сирил Рамафоса. Президент Нигера Махамаду Иссуфу написал о необходимости реализации «плана Маршалла для Африки» [17].

При всей очевидности потребности Черного континента в финансовой, технологической, медицинской, продовольственной помощи со стороны «великих держав» не стоит забывать о том, что такая помощь никогда не бывала бескорыстной. Международный валютный фонд, Всемирный банк, финансовые структуры отдельных развитых стран охотно предоставляют помощь африканцам, однако последние неизбежно расплачиваются распродажей своих природных ресурсов по демпинговым ценам, политическими уступками, размещением на своей территории военных баз. И в этом контексте неожиданно прозвучало предложение президента Франции «простить» беднейшим африканским странам их государственные задолженности.

\section{Инициативы Эммануэля Макрона}

Накануне саммита G20-finance 15 апреля 2020 г. президент Франции Эммануэль Макрон предложил лидерам «двадцатки» поддержать африканские страны, столкнувшиеся с угрозой пандемии. Он призвал министров финансов стран, входящих в G20, согласиться на приостановку выплат по долгам. «На период кризиса мы должны обеспечить африканским экономикам передышку, чтобы они не были скованы выплатами по долгам», - сказал Макрон, объявив, что «мораторий станет щагом к окончательному списанию африканского долга» [30].

В интервью «Radio France Internationale» (RFI) Президент Франции призвал к массовой отмене суверенного долга континента. Мораторий позволит африканским странам «дышать, а не платить проценты», сказал он. В конце этого интервью Э. Макрон выступил с радикальным предложением: «Я за масштабную инициативу по списанию долга» [13].

Во время интервью RFI журналист Кристоф Бойсбувир напомнил главе французского государства, что 40\% текущих долговых обязательств африканских стран - это кредиты, полученные от Китайской Народной Республики. Журналист поинтересовался, беседовал ли Макрон с председателем КНР Си Цзиньпином и согласен ли тот отсрочить выплаты по долгам или даже списать африканские долги? Ответ Макрона был уклончивым. Он вынужден был признать, что 
он не обсуждал эту проблему с китайским лидером, при этом выразил уверенность в том, что «для президента Китая ситуация в Африке сегодня оправдывает такой жест» и что «такое обсуждение может состоятся в ближайшие дни или в ближайшие несколько недель» [13]. По мнению президента Франции, Китай должен «сделать такой жест» [Там же]. При этом Э. Макрон предпочитает не вспоминать о том, что в 2019 г. Китай без всяких внешних побуждений согласился реструктурировать или даже частично списать долги некоторых африканских стран, включая Республику Конго и Камерун.

Шумно разрекламированная инициатива президента Пятой Республики, однако, не отличается новизной. Еще в 2019 г. на сочинском саммите «Россия-Африка» Владимир Путин объявил о том, что Россия в одностороннем порядке уже списала африканским странам долги в 20 млрд доларов.

\section{Смысл популистской риторики Эммануэля Макрона}

Призывая кредиторов Европы, США и Китая отказаться от совокупного африканского долга на сумму 365 млрд доларов, Макрон, вероятно понимал, что эта инициатива не встретит поддержки у лидеров стран-членов «двадцатки». Однако он рассчитывал на то, что призыв к спасанию долгов африканских стран принесет ему ощутимые политические дивиденды и будет способствовать укреплению имиджа главного радетеля интересов африканцев. Соответственно, главный и самый опасный конкурент Пятой республики на Черном континенте Китай будет выглядеть в глазах страдающих от пандемии жителей африканских стран едва ли не основным виновником обнищания и массовой гибели людей.

Беспроигрышная позиция! Если даже допустить, что страны «двадцатки» согласятся на предложение хозяина Елисейского дворца, то Франция окажется в выигрыше в этой сложной политической игре. Дело в том, что главным инструментом экономической экспансии Китая в Африке с начала нынешнего столетия стало щедрое кредитование и инвестирование масштабных инфраструктурных проектов африканских стран. Разумеется, долговая зависимость бедных африканских стран от Китайской Народной Республики влечет за собой и все более тесное политическое и военное (создание военно-морской базы в Джибути) сотрудничество этих субъектов международного права с Поднебесной. Тринадцать лет назад главными торговыми партнерами африканских государств были (в порядке убывания) США, Китай и Франция. Сегодня это Китай, затем Индия и США. Франция оказалась 
на седьмом месте [15]. В итоге китайские деньги и технологии стали одними из главных драйверов развития африканских экономик [27]. Пятая республика не выдерживает экономического противоборства с КНР и в конечном итоге обречена на поражение. Э. Макрон прекрасно понимает это и всеми силами пытается противостоять «выдавливанию» Франции из африканского геополитического пространства. Во время поездки по странам Африканского Рога он попытался убедить своих африканских коллег в том, что расширение влияния КНР в Африке угрожает национальному суверенитету их стран и интересам их исторических партнеров. Однако нельзя сказать, что ему это удалось. Показательно в этом контексте шутка влиятельного джибутийского дипломата: «У французов нет денег, с коммерческой точки зрения они не имеют большого значения для нас... Макрон прибежал к нам от “желтых жилетов”» [25].

В сложившейся ситуации «обнуление» африканских долгов всех стран-кредиторов было бы чрезвычайно выгодно для Франции. Это позволило бы вновь вернуться на исходные позиции в завоевании политических преференций в отношениях со странами африканского континента. Но это понимает не только Макрон, но и его коллеги из стран «двадцатки». В эксклюзивном интервью RFI 14 апреля 2020 г. президент Франции сказал, что в краткосрочной перспективе он лишь надеется, что во время G20-finance будет введен мораторий на задолженность африканских стран, а в долгосрочной перспективе он хочет массового списания этого долга [13]. Возникает ощущение, что это не более чем фигура речи.

\section{Политическая демагогия и политические практики}

Судя по всему, и сам французский президент не собирается списывать долги африканских стран в одностороннем порядке. Об этом свидетельствуют отдельные высказывания его соратников и подчиненных.

Накануне мартовского саммита «двадцатки» министр экономики Франции Брюно Ле Мэр сказал, что его коллеги в Соединенных Штатах, Китае, Европе и других членах группы крупнейших экономик G20 обсудят планы приостановить выллаты по долгам для 76 стран, в т.ч. 40 стран Африки к югу от Сахары. Высокопоставленный дипломат c Quaid' Orsay (Набережной Орси, т.е. МИД Франции) на условиях анонимности сказал, что «его страна не поднимет идею об отмене долгов сразу, а вместо этого первоначально предложит мораторий и реструктуризацию» [23]. А его коллега, принимавший участие в подготовки саммита G20, добавил, что «согласиться на мораторий будет проще, чем на полное списание африканских долгов» [Там же]. 
Как это не парадоксально, практически одновременно с разговорами о списании и замораживании долгов французское правительство объявило, что Пятая республика «направляет» около 1,2 млрд евро для оказания помощи африканским странам в борьбе с коронавирусом. «Ситуация требует особой бдительности», - заявил министр иностранных дел Франции Жан Ив Ле Дриан. После чего Французское агентство развития (AFD) конкретизировало заявление Елисейского дворца, пояснив, что 1,2 млрд евро будут состоять из 150 млн евро пожертвований и 1 млрд евро в виде кредитов [20]. Предлагая лидерам «двадцатки» списать долги, Елисейский дворец навязывает африканцам кабальные кредиты, расплатиться по которым африканские страны никогда не смогут, а значит, еще долго будут сохранять зависимость от Пятой республики!

\section{Телеконференция Макрона с лидерами десяти африканских стран}

В начале апреля 2020 г. Елисейский дворец объявил об отмене саммита «Африка - Франция» (его проведение во французском Бордо было запланировано на июнь) и о предстоящей «инициативе, посвященной здравоохранению и экономическому реагированию на COVID-19 на всем континенте» [17]. 3 апреля Э. Макрон и десять лидеров африканских государств принимали участие в телеконференции, которая была организована с целью обсуждения этой «инициативы» . Во встрече принимали участие президенты Ибрагим Бубакар Кейта (Мали), Абий Ахмед (Эфиопия), Кирилл Рамафоса (Южная Африка), Пол Кагаме (Руанда), Макки Салл (Сенегал), Феликс Тшисекеди (Демократическая Республика Конго), Абдель Фаттах аль-Сисси (Египет), Ухуру Кеньятта (Кения), Эммерсон Мнангагва (Зимбабве) и Мусса Факи - председатель Комиссии Африканского союза. Сам по себе список участников этого мероприятия представляет большой интерес, поскольку позволяет судить о том, на чью поддержку может рассчитывать Макрон в предстоящих политических катаклизмах.

Более подробной информации администрация Елисейского дворца не предоставила, но известно, что непосредственно перед этой телеконференцией специалисты Центра анализа, прогнозирования и стратегии (CAPS), экспертного сообщества МИД, направили французскому президенту аналитический доклад «Эффект панголина: грядущий шторм в Африке», который был опубликован 1 апреля газетой La Tribune. Авторы этого документа считают, что «предстоящая ударная волна COVID-19 в Африке может быть слишком сильным ударом по государ- 
ственным аппаратам африканских стран» [12]. Они предлагают готовиться к «длительной дестабилизации» в Африке в условиях «предстоящего кризиса обществ и государств» [Там же]. Известные французские дипломаты предупреждают, что кризис может уничтожить «хрупкие режимыл» в Сахеле и несколько позже - в Центральной Африке. Они полагают, что коронавирус может стать «политическим вирусом, который в массовом порядке покажет неспособность этих государств защитить свое население» [Там же]. При этом аналитики CAPS указывают на особую уязвимость «некоторых экономически слабых и политически нестабильных франкоязычных стран, менее надежных и структурированных, чем другие» [Там же].

В этом утверждении фактически содержится признание порочности африканской политики Пятой республики, насаждавшей слабых и непопулярных лидеров и разорявшей франкофонные государства, бывшие прежде колониями Французской империи. В этом контексте стоит отметить, что в странах Тропической Африки быстро нарастает антифранцузское протестное движение. Констатация этого факта все чаще появляется на страницах французских газет. Вот пример: специальный корреспондент агентства France 24 Кловис Казали пишет по этому поводу: «В последнее время президент Франции критиковал тех, кто осуждает французское присутствие в странах Западной Африки. Он не понимает это недовольство гражданского населения и некоторых политиков» [28]. Дело дошло до того, что Макрон предупредил своих африканских коллег о возможности сокращения участия или даже о выходе Франции из операции «Бархан» (операция французских войск в Сахеле, призванная сдерживать террористические акции исламистов). Он потребовал, чтобы лидеры стран Западной Африки публично подтвердили свою поддержку военного присутствия Франции на своей территории. Не выдержав давления Елисейского дворца, президенты африканских стран вынуждены были подписать совместную декларацию, в которой они подтвердили свое «одобрение военного присутствия французских военных в регионе» [Там же]. А это, в свою очередь, вызвало новую волну протестов в странах Сахеля.

Авторы доклада «Эффект панголина: грядущий шторм в Африке» считают, что «сравнение определенных государств, чья государственная политика терпит неудачу (государства Сахеля и Центральной Африки) с другими африканскими странами, обладающими более прочными властными институтами (например, Руанда или Сенегал) было бы «неблагоприятно» для первых. «Эффект сравнения» может стать дополнительным конфликтогенным фактором и привести к смене политических элит. Дипломаты Quai d’Orsay полагают, что прямым следствием 
пандемии коронавируса станет «жесткая конкуренция» за передел геополитического и экономического пространства на африканском континенте и предрекают «захват Африки Китаем» [12].

Можно с большой долей уверенности предположить, что именно поискам выхода из предстоящего политического кризиса и была посвящена телеконференция с участием лидеров десяти африканских стран, наиболее лояльных Елисейскому дворцу.

\section{Перспективы развития геополитической ситуации в посткоронавирусный период}

За последнее десятилетие геополитический ландшафт в мире претерпел серьезные изменения. «Рельефно обозначился процесс перераспределения в глобальных масштабах силы и влияния, укрепления новых полюсов формирующейся полицентричной международной системы» [9, с. 3].

Экономическая экспансия Китая в Африку стало фактом уже в начале тысячелетия, но особенно заметным она стала во втором десятилетии нынешнего столетия. Если двадцать лет назад перемены в Африке мало отражались на Китае, то сейчас «в силу растущей вовлеченности Китая в дела Африки события на континенте непосредственно затрагивают его интересы» [1, с. 59-370; 3, с. 96]. В начале второго десятилетия XXI в. КНР установила тесные связи с такими странами, как Кот-д’Ивуар, Сенегал, Нигерия и Габон. В настоящее время быстро развивается сотрудничество с Египтом, Кенией, Эфиопией, Джибути, Суданом и другими странами континента. Китайские компании наращивают свое присутствие в строительном секторе и добывающей промышленности африканских стран, а китайские инвесторы финансируют африканские проекты, прежде всего, в сфере энергетики и логистики. Китай активно борется за передел африканских ресурсов и рынков (см. подробно: [1, с. 59-370; 2, с. 84-91; 5, с. 32-42; 8]).

Многие исследователи констатируют, что по мере становления новой биполярности» КНР вышла на «лидирующие позиции среди доноров в целом ряде стран» [3, с. 96]. Китай активно продвигает на африканском континенте проект «Один пояс - один путь». В 2014 г. был создан фонд (40 млрд дол.), нацеленный на поддержку инфраструктурных проектов африканских стран. В декабре 2015 г. был подписан меморандум между КНР и Африканским союзом, который предусматривает строительство стратегически важных транспортных узлов, например, ЧадСудан или Найроби-Момбаса. В мае 2017 г. на форуме «Один пояс один путь» в Пекине Си Цзиньпин объявил о готовности КНР вложить 
в этот проект дополнительно 124 млрд дол. [3, с. 96]. Реализация этого проекта предполагает строительство железных дорог, реорганизацию авиационного сообщения, создание технопарков. В сентябре 2018 г. в Пекине состоялся китайско-африканский саммит, на котором присутствовали лидеры практически всех африканских стран. По итогам этого масштабного форума была подписана «Пекинская декларация о построении китайско-африканского сообщества единой судьбы», в которой КНР объявила о своей готовности выделить ряду стран Африки финансовую помощь в размере 60 млрд дол.

Однако не только Поднебесная стремится к замещению «великих держав» на Африканском континенте. Начиная с 2006 г. Россия постепенно восстанавливает утраченные в 1990-е гг. позиции в африканских странах. Недружественные по отношению к России СМИ констатируют: «Влияние России в Африке растет от Судана до Анголы. Наследники Советского Союза не ограничиваются политическим вмешательством, занимаясь одновременно беспринципным бизнесом» [цит. по: 4]. Рассуждая об изменениях политического ландшафта Африки южнее Сахары, многие западные обозреватели отмечают, что «Москва сделала себя необходимой в таких странах, как Судан, Ангола, Мозамбик и Нигерия. Тесные отношения существуют у нее также с Эфиопией и Зимбабве» [26]. Все чаще говорят о «дуге российского влияния», которая протянулась из Судана в Анголу, от Хартума до Луанды через Банги и Киншасу [18].

Особенно агрессивными стали нападки на Россию после того, как в январе 2018 г. военный транспорт Ил-76 совершил первую посадку в аэропорту Банги. Артем Кожин, официальный представитель МИД РФ, в марте 2018 г. объявил, что с разрешения ООН «на нужды центральноафриканской армии в конце января - начале февраля 2018 г. была поставлена партия стрелкового вооружения и боеприпасов. Туда также командированы 5 военных и 170 российских гражданских инструкторов для подготовки военнослужащих ЦАР» [21]. Российские политические обозреватели Юрий Сафронов и Ирек Муртазин, «внимательно ознакомившись с открытыми французскими и африканскими источниками», пришли к выводу о том, что в ЦАР «сейчас не только идет очередная гражданская война, но и совершается попытка смены колонизатора» [6].

Француз Тома Дьетрик упрекает «наследников СССР» в том, что у них «политическое вмешательство неизбежно сопровождается экономической экспансией» и предостерегает от «недооценки российских амбиций к югу от Сахары» [18]. По мнению этого французского политолога, «аферизм российских инвесторов с мафиозными пристрастиями предполагает попытку восстановить Российскую Империю на земле 
Африки» [18]. Еще совсем недавно «Франция не скрывала своего пренебрежения к России, которая двигает свои пешки в Центральноафриканской Республике» [14]. Используя дипломатическую поддержку союзников по НАТО и опираясь на созданную усилиями генерала Де Голля военно-политическую систему «Франсафрик» [подробно см.: 7], Елисейский дворец практически полновластно использовал ресурсы франкоязычных стран Тропической Африки. Но вдруг это безусловное доминирование было поставлено под сомнение. Т. Дьетрик задается риторическим вопросом: «Неужели Франция теряет позиции в Центральноафриканской республике?» и отвечает на него утвердительно: «Недавние события указывают на это; в Париже видят, что его влияние в ЦАР ослабло до тоненького ручейка» [18]. Его коллеги Шарль Буссель и Эмре Сари пытаются найти ответ на вопрос «почему в этой объятой хаосом стране, прежде находившейся в зоне влияния Франции, теперь столь очевидно военное присутствие России?» [цит. по: 11].

Известный французский политолог Арно Дюбьен справедливо заметил, что «сегодня Россия пытается превратить старые узы идеологической дружбы (там, где они еще существуют) в геоэкономическое влияние» [19]. Мобилизуя старые стереотипы борьбы с колониализмом и экспансией Запада, Россия возвращается на Черный континент не только с контрактами, но и с бойцами частных военных компаний. Теперь речь идет не только о геоэкономическом, но и о геополитическом влиянии. Сейчас в западном экспертном сообществе возобладало мнение, согласно которому Россия стремится расширять свое присутствие на Черном континенте. Пожелавший остаться неназванным чиновник из структур ООН констатировал: «Все они (страны Запада) встревожены, они не знают, что делать. Они не ожидали прихода русских!» [29].

Есть основания думать, что Россия и Китай смогут договориться о совместных действиях на просторах Черного континента. Так, например, после размещения бойцов российской частной военной компании «Вагнер» в ЦАР, российские и китайские частные компании при политической поддержке Москвы и Пекина начали добычу алмазов в Бриа и в районе Берберати.

Все это не может не беспокоить руководство Франции: рост влияния КНР и России в африканских странах серьезно угрожает интересам Пятой республики. Для Франции потеря политических и экономических преференций, которыми она пользовалась в странах, входивших некогда в состав Французской колониальной империи, станет, без преувеличения, катастрофой [24]. В желании во что бы то ни стало вернуть утраченные позиции в африканских странах, Э. Макрон пытается опереться, 
прежде всего, на исторических «партнеров» Пятой республики. Однако в поисках новых рычагов влияния на юге и востоке континента он делает все, чтобы завоевать симпатии англоязычных африканских стран, ранее не входивших в сферу влияния Франции.

Китай, раньше других начавший выходить из пандемии и преодолевать экономический кризис, вероятнее всего, использует сложившеюся ситуацию для дальнейшего продвижения своих интересов на африканском континенте. В условиях пандемии, когда Черный континент будет как никогда нуждаться во внешней помощи, Китай будет завоевывать новых друзей, оказывая поддержку слабым африканским экономикам Тропической Африки. А у Франции в условиях экономического кризиса и предстоящей затяжной рецессии на это просто нет и еще долго не будет денег. В марте 2020 г. министр экономики Брюно Ле Мэр на канале $R T L$ объявил, что правительство предполагает сокращение ВВП на 1\% в 2020 г. «Нас ожидает явное ухудшение ситуации», - сказал министр. При этом он подчеркнул, что прогноз падения ВВП на 1\% является предварительным показателем ${ }^{1}$ и что вся еврозона окажется в состоянии рецессии.

Такой сценарий совершенно не устраивает Белый дом. Есть все основания думать, что в сложившейся ситуации Пентагон отчасти пересмотрит принятое в конце 2019 г. решение о минимизации военного присутствия в Африке и прекращении поддержки французских военных в Сахеле. Ведь завершение операции «Бархан» и исход Франции из стран субсахарской Африки, окончательное замещение Пятой Республики в этих странах Китаем и Россией в корне противоречит долгосрочным геополитическим интересам США.

Напомню, что в конце прошлого года американское издание The New York Times сообщило, что глава Пентагона Марк Эспер рассматривает возможность сокращения или полного вывода американских войск из стран Субсахарской Африки. Стало известно, что он приказал Африканскому командованию ВС США (Африком) подготовить комплексный план по выводу войск из Сахеля. Согласно этому плану США должны покинуть свою военную базу в Нигере, а также прекратить поддержку Франции в борьбе с исламистами в Мали, Нигере и Буркина-Фасо. 13 января 2020 г. на встрече с коллегами по НАТО в Брюсселе председатель Объединенного комитета начальников штабов США генерал Марк Милли подтвердил информацию о том, что Белый дом рассматривает возможность масштабного сокращения военного

\footnotetext{
${ }^{1}$ На конец августа падение ВВП во Франции составило почти 14\% (https://ru.euronews. com/2020/07/31/france-gdp-contraction). - Прим. ред.
} 
присутствия в Тропической Африке. Однако с началом пандемии коронавируса последовало разъяснение. «Мы скорректируем присутствие в Африке», - сказал глава Пентагона Марк Эспер [12]. Он не стал уточнять, как именно будет реализована такая корректировка, но пояснил, что реализация ее будет осуществляться в рамках стратегии конкуренции с мировыми державами - Россией и Китаем, и подчеркнул, что Пентагон в сложившихся условиях не намерен полностью выводить свои силы из Африки.

Глобальный экономический кризис многократно усилил риски Пятой республики в Тропической Африке. Именно поэтому эксперты французского МИДа называют политические режимы стран Сахеля и Центральной Африки «хрупкими» и предрекают смену непопулярных властных элит, которые остаются у власти только благодаря протекционизму со стороны Елисейского дворца. Россия в этой ситуации должна стремиться занять лакуны в геополитическом и, соответственно, экономическом пространстве Тропической Африки в тандеме с КНР. В этом контексте имело бы смысл заблаговременно установить или интенсифицировать контакты с контрэлитами в странах региона, с лидерами оппозиции и наиболее харизматичными представителями молодежного движения.

\section{Библиографический список / References}

1. Африка: современные стратегии экономического развития / Под ред. И.О. Абрамовой, Е.В. Морозенской. М., 2016. [Afrika: sovremennye strategii ekonomicheskogo razvitiya [Africa: Current economic development strategies]. I.O. Abramova, E.V. Morozenskaj (eds.). Moscow, 2016.]

2. Дегтерев Д.А. Китай-Африка: важные аспекты отношений // Мировая экономика и международные отношения. 2005. № 5. C. 84-91. [Degterev D.A. China-Africa: Important aspects of relations. World Economy and International Relations. 2005. No. 5. Pp. 84-91. (In Russ.)]

3. Дейч Т.Л. Политика Китая в странах Северной Африки и Средиземноморья // Ученые записки Института Африки РАН. 2018. № 2 (43). C. 95-110. [Deutsch T.L. Politics of China in the countries of North Africa and the Mediterranean. Scientific Notes of the Institute for African Studies RAS. 2018. No. 2 (43). Pp. 95-110. (In Russ.)]

4. Нелюбин Е. Президент ЦАР доверил свою безопасность россиянам. URL: https://www.bfm.ru/news/391294 (дата обращения: 09.01.2020). [Nelyubin E. Prezident TsAR doveril svoyu bezopasnost rossiyanam [The President of the Central African Republic entrusted his safety to the Russians]. URL: https://www.bfm.ru/news/391294]

5. Пономаренко Л.В., Соловьева Т.М. КНР - Африка: новые ориентиры взаимоотношений // Вестник Российского университета дружбы народов. Серия: Международные отношения. 2015. № 1. С. 32-42. 
[Ponomarenko L.V., Solovieva T.M. China - Africa: New guidelines for relations. Vestnik RUDN. International Relations. 2015. No. 1. Pp. 32-42. (In Russ.)]

6. Сафронов Ю., Муртазин И. Нам нужен свой ЦАР? // Новая газета. 2018. № 83. 3 августа. URL: https:/www.novayagazeta.ru/articles/2018/08/02/77376nam-nuzhen-svoy-tsar [Safronov Yu., Murtazin I. Do we need our own CAR? Novaya gazeta. 2018. No. 83. August 3. URL: https://www.novayagazeta.ru/ articles/2018/08/02/77376-nam-nuzhen-svoy-tsar (In Russ.)]

7. Филиппов В.P. «Франсафрик»: тень Елисейского дворца над Черным континентом. M., 2016. [Filippov V.R. «Fransafrik»: ten Elisejskogo dvorca nad Chernym kontinentom ["Francafric": The shadow of the Champs Elysees over the Black Continent]. Moscow, 2016.]

8. Фитуни Л.Л. Африка: ресурсные войны XXI века. M., 2012. [Fituni L.L. Afrika: resursnye vojny XXI veka [Fituni L.L. Africa: 21st century resource wars]. Moscow, 2012.]

9. Фитуни Л.Л., Абрамова И.О. Закономерности формирования и смены моделей мирового экономического развития // Мировая экономика и международные отношения. 2012. № 7. C. 3-15. [Fituni L.L., Abramova I.O. Patterns of formation and change of models of world economic development. World Economy and International Relations. 2012. No. 7. Pp. 3-15. (In Russ.)]

10. Abiy A. What African economies need to survive the coronavirus. URL: https:// www.bloomberg.com/opinion/articles/2020-04-12/africa-needs-imf-debt-reliefto-survive-the-coronavirus (accessed: 09.01.2020).

11. Airault P. Le Drian reprend en main le dossier centrafricain. URL: https:// www.lopinion.fr/edition/international/drian-reprend-en-main-dossiercentrafricain-152594 (accessed: 09.01.2020).

12. Bobin F., Tilouine J. Coronavirus : les experts du Quai d'Orsay redoutent le «coup de trop» qui «déstabilise» l'Afrique. URL: https:/www.lemonde.fr/ afrique/article/2020/04/03/coronavirus-les-experts-du-quai-d-orsay-redoutentle-coup-de-trop-qui-destabilise-1-afrique_6035470_3212.html (accessed: 06.06.2020).

13. Boisbouvier C. Emmanuel Macron sur RFI : «Nous devons la solidarité à l'Afrique» face au coronavirus. URL: http://www.rfi.fr/fr/podcasts/20200415emmanuel-macron-rfi-afrique-raoult-coronavirus-covid-dette (accessed: 03.06.2020).

14. Centrafrique : depuis Bangui, Jean-Yves Le Drian annonce la fin de l'opération Sangaris. URL: http://www.jeuneafrique.com/370296/politique/centrafriquebangui-jean-yves-drian-annonce-fin-de-loperation-sangaris/ (accessed: 09.01.2020).

15. Clemenceau F. Emmanuel Macron et la Chine en Afrique, un vrai sujet. Le Journal du Dimanche. 16.03.2019. URL: https://www.lejdd.fr/International/ emmanuel-macron-et-la-chine-en-afrique-un-vrai-sujet-3875261 (accessed: 10.01.2020).

16. Coronavirus in Africa: Contained or unrecorded? URL: https://www.bbc.com/ news/world-africa-52702838 (accessed: 09.05.2020).

17. Coronavirus : Macron et dix dirigeants africains discutent d'un effort coordonné. URL: https://www.lemonde.fr/afrique/article/2020/04/04/coronavirus-macronet-dix-dirigeants-africains-discutent-d-un-effort-coordonne_6035551_3212. html (accessed: 09.06.2020). 
18. Dietrich T. En Centrafrique, un parfum de guerre froide. URL: https:/www. lopinion.fr/edition/international/en-centrafrique-parfum-guerre-froide-156731 (accessed: 09.01.2020).

19. Dubien A. La Russie s'intéresse également à la nouvelle Afrique. URL: http:// afrique.lepoint.fr/economie/arnaud-dubien-la-russie-s-interesse-egalementa-la-nouvelle-afrique-page-2-25-10-2017-2167405_2258.php (accessed: 09.01.2020).

20. Finnan D. France stumps up $€ 1$ bn of loans for Africa's fight against coronavirus. URL: http://www.rfi.fr/en/africa/20200410-france-stumps-up$\% \mathrm{E} 2 \% 82 \% \mathrm{AC} 1 \mathrm{bn}-$ of-loans-for-africa-s-fight-against-coronavirus (accessed: 03.06.2020).

21. Kirilenko A. Blood Diamonds. Who killed Russian journalists in the CAR, and what do Putin's Chef and St. Petersburg police have to do with it? URL: https:// theins.ru/uncategorized/114123?lang=en (accessed: 01.02.2020).

22. Lesotho becomes last African country to record coronavirus case. URL: https:// www.aljazeera.com/news/2020/05/lesotho-african-country-record-coronaviruscase-200513154809818.html (accessed: 01.06.2020).

23. Nussbaum A. France Expects G-20 to Offer African Nations Debt Moratorium. URL: https://www.bloomberg.com/news/articles/2020-04-15/africa-debtmoratorium-is-essential-amid-outbreak-macron-says (accessed: 09.05.2020).

24. Philippov V.R. Uranium factor in france's foreign policy towards Africa. Sententia. European Journal of Humanities and Social Sciences. 2015. No. 2. Pp. 171-185.

25. Semo M. Emmanuel Macron en visite à Djibouti, où l'influence de la France recule face à la Chine. URL: https://www.lemonde.fr/afrique/article/2019/03/12/ emmanuel-macron-en-visite-a-djibouti-ou-l-influence-de-la-france-recule-facea-la-chine_5434898_3212.html (accessed: 07.06.2020).

26. Signer D. Wie Russland afrikanische Krisenländer infiltriert. URL: https:// www.nzz.ch/international/wie-russland-afrikanische-krisenlaender-infiltriertld.1389297 (accessed: 09.03.2019).

27. Sindzingre A. The ambivalent impact of commodities: Structural change or status quo in Sub-Saharan Africa? South African Journal of International Affairs. 2013. No. 20. Pp. 23-55.

28. Sommet du G5 Sahel à Pau : Emmanuel Macron veut resserrer le front antijihadiste. URL: https://www.france24.com/fr/20200113-un-sommetdu-g5-sahel-\%C3\%A0-pau-pour-resserrer-le-front-antijihadiste (accessed 04.01.2020)

29. Tchad anthropus-tribune. Centrafrique : Au porte du Tchad, Bangui flirte avec les veillées expansionnistes de Poutine. URL: http://www.letchadanthropustribune.com/tchad-centrafrique-au-porte-du-tchad-bangui-flirte-avec-lesveillees-expansionnistes-de-poutine (accessed: 03.04.2020).

30. Woods M. Macron calls for suspension of debt to help Africa deal with coronavirus. URL: http://www.rfi.fr/en/africa/20200415-macron-calls-forsuspension-of-debt-to-africa-deal-with-coronavirus-g20-repayments-covid-19 (accessed: 04.06.2020). 
Сведения об авторе / About the author

Филиппов Василий Рудольфович - доктор исторических наук; ведущий научный сотрудник Центра изучения стран Тропической Африки, Институт Африки Российской академии наук

Vasily R. Filippov - Dr. Hab. (Historical Sciences); Leading Researcher at the Center for the Study of the Countries of Tropical Africa, Institute for African Studies of the Russian Academy of Sciences

E-mail: fvr1957@mail.ru 